Araştırma Makalesi

(Research Article)

Mithat Nuri GEVREK

\section{Determination of The Adaptation of Some Azolla (Azolla anabaena L) Genotypes to The Mediterranean and Aegean Coastline Ecological Conditions}

\author{
Bazı Azolla (Azolla anabaena L) Genotiplerinin Akdeniz ve Ege \\ Kıyı Kuşağına Adaptasyonunun Belirlenmesi
}

Alınış (Received): 15.09.2014 Kabul tarihi (Accepted): 10.02.2015
Ege University, Faculty of Agriculture, Department of Field Crops, 35100 Izmir /Turkey e-mail: mithat.gevrek@ege.edu.tr

\section{Key Words:}

Azolla species, dry weight, organic plant nutrient

\section{Anahtar Sözcükler:}

Azolla türleri, kuru ağırlık, organik bitki besin maddesi

\begin{abstract}
The objective of this study was to determine the adaptation of some azolla (Azolla anabaena) genotypes to the Mediterranean and Aegean coastline ecological conditions. The research was carried out in the research fields of Faculty of Agriculture, Aegean University in Menemen-İzmir during 2002-2003 and 2003-2004. In the trial, five genotypes belong to four Azolla species were used. Fresh azolla plants were inoculated at a rate of $300 \mathrm{~g} \mathrm{~m}^{-2}$ into ponds for each month, they were harvested 14 days after inoculation and dry matter $(\mathrm{g} \mathrm{m}$ $\left.{ }^{2}\right)$ was determined. The results of the study showed that the genotypes FI-1040 and MI-4030 could be adaptable to the Mediterranean and Aegean coastline ecological conditions. Their dry weights were 67.8 and $68.2 \mathrm{~g} \mathrm{~m}^{-2}$ after fourteen days, respectively. The annual dry matter production reached to 16 ton ha:
\end{abstract}

\section{ÖZET}

u çalışmada bazı azolla (Azolla anabaena L.) genotiplerinin Akdeniz-Ege kıyı kuşağına adaptasyonunun belirlenmesi amaçlanmıştır. Araştırma 20022003 ve 2003-2004 yıllarında Ege Üniversitesi Ziraat Fakültesi'nin Menemen Uygulama Çiftliğinde yürütülmştür. Denemede, dört Azolla türüne ait beş genotip kullanılmıştır. Metrekareye $300 \mathrm{~g}$ taze azola aşılanmış ve $14 \mathrm{gün}$ sonra hasat edilmiştir. Genotiplerden FI-1040 ve MI-4030'un Ege-Akdeniz kıyı şeridi ekolojik koşullarına uyum sağladığı anlaşılmıştır. Her iki genotipin 14 gün sonra kuru madde ağırlığının sırasıyla $67.8 \mathrm{~g} \mathrm{~m}^{-2}$ ve $68.2 \mathrm{~g} \mathrm{~m}^{-2}$ olduğu, yıllık kuru madde üretiminin ise ortalama 16 ton ha'`a ulaştığı anlaşılmıştır.

\section{INTRODUCTION}

Azolla (Azolla anabaena L.) is known as an aquatic fern which lives on the water surface of rice fields, small ponds and rivers. Azolla covers the water surface quickly and it is situated harmoniously under the canopy of rice plants without affecting its growth. Azolla generally reproduces asexually by splitting and often sexually.

The size of the fern varies between $1-5 \mathrm{~cm}$ and there are lops observed on its leaves. The blue-green algae Anabaena azollae lives on the leaves of azolla and a symbiotic association is characterized in terms of nitrogen fixation. Anabaena azollae is stated as able to fix $3-5 \mathrm{~kg} \mathrm{~N}$ per day under favorable conditions. Taking advantages of the nitrogen fixing blue-green algae, Azolla can double its weight within 3-5 days (Ashton, 1971; Talley et al., 1977; Venture and Watanabe, 1990).

As a result of its nitrogen fixation ability and high nitrogen content, azolla has been used as a green 
manure and resource of organic matter for the wetland rice in northern Vietnam and central China for centuries. About $70 \%$ of $\mathrm{N}$ content of azolla is mineralized to $\mathrm{NH}_{4}{ }^{+} \mathrm{H}$ after 20 days from symbiosis (Venture et al., 1990). On the other hand, it can be also converted into compost to be used for dry land crops and vegetables. At present, azolla is used in more than a million hectares of rice lands in China. Azolla usage in rice production has been increasing in Philippines. It is estimated that $44 \%$ of rice lands will be fertilized with azolla in near future. Azolla has high protein content, its protein content approximately 2-37\% on dry matter base and it has also been used for animal feeding such as pigs, ducks, and fishes (Watanabe et al., 1977; Thomas et al., 1982; Hove, 1989).

Azolla is known as sensitive to desiccation and the optimum growth temperature is noted as $25^{\circ} \mathrm{C}$, however the aquatic fern can tolerate low temperatures up to $-5^{\circ} \mathrm{C}$ (Watanabe et al., 1977). Seven different azolla species are known and four of them are originated from U.S.A. The results of the researches showed that Asia and Ocean originated $A$. pinnate increased $20 \%$ of rice yield when it was used as green manure. On the other hand, the U.S.A. originated species $A$. carolina, $A$. filiculoides and $A$. mexicana adapted to the temperate ecological conditions increased paddy yield between $23 \%$ and $67 \%$ (Watanabe et al., 1977; Thomas et al., 1982; Hove, 1989).

The advantage of the azolla genotypes are fast growth ability, higher nutrient content and organic matter values and they can be adapted to the temperate ecological conditions. These advantages make azolla a promising green manure for Mediterranean conditions. Also, it is known that $A$. filiculoides is naturally grown in rice production areas of Trakya region in Turkey (Aysel and Gevrek, 2003).

This research aims to evaluate the adaptation and dry weight values of five azolla genotypes, which belong to four different species ( $A$. caroliniana, $A$. microphylla, $A$. filiculoides and $A$. mexicana) in Mediterranean and Aegean coastline ecological conditions.

\section{MATERIALS and METHODS}

The study was carried out at Menemen Location (Aegean Region, Western Turkey) during the years 2002-2004.

In the trial, five genotypes belong to four azolla species were used. Three of genotypes were obtained from IRRI (The International Rice Research Institute), one genotyp from rice production areas and the fift one from $A$. mexicana which understood to be adapted to the Aegean-Mediterranean coastal conditions in previous studies (Gevrek et al., 2004). This genotype was used as control in the study. The characterictics of azolla genotypes used in the trial were shown in Table 1.

The experiment design was randomized complete block desing with three replicates. The trial was conducted for two years. The experiment was arranged as $5 \times 12$ factorial design (genotypes $\mathrm{x}$ months). Table 2 shows the average air temperatures and relative humidity of Menemen location. Inoculation dates of genotypes were shown in Table 3.

Fresh azolla plants were inoculated at a rate of 300 $\mathrm{g} \mathrm{m}^{-2}$ into ponds of $4 \mathrm{~m} \times 4 \mathrm{~m} \times 4 \mathrm{~m}\left(16 \mathrm{~m}^{2}\right)$. Inoculation dates of different genotypes are shown on Table 1.The pods were constantly stagnant with a water level of 20 $\mathrm{cm}$. To promote the vegetative growth of azolla plants and nitrogen fixation of Anabaena algae, $0.20 \mathrm{~g} \mathrm{~m}^{-2}$ of $\mathrm{P}_{2} \mathrm{O}_{5}$ was applied to the ponds as triple super phosphate (Khan 1987; Hove 1989). The soil texture of the study fields was determined as silty loam.

Fresh azolla plants were collected by hand 14 days after inoculation and dry matter $\left(\mathrm{g} \mathrm{m}^{-2}\right)$ was determined. Data was analyzed by using standard ANOVA. The means were compared by using the LSD test described by Steel and Torrie (1980).

Table 1. Information related to azolla genetic material used in the study (Watanabe, et al., 1992, Aysel and Gevrek, 2003).

\begin{tabular}{clll}
\hline Variety No. & Species & Code & Characteristics \\
\hline $\mathbf{1}$ & A. filiculoides & Fl-1040 & Highly reproductive by spores \\
$\mathbf{2}$ & A. caroliniana & CA-3510 & Highly reproductive by spores \\
$\mathbf{3}$ & A. microphylla & MI-4030 & Nitrogen rate on dry matter is \% 4. Highly productive \\
$\mathbf{4}$ & A. filiculoides & AF & Adapted to the ecological conditions of Trakya. \\
$\mathbf{5}$ & A. mexicana & ME-2026 & Highly reproductive by spores and high vegetative growth capacity \\
\hline
\end{tabular}


Determination of The Adaptation of Some Azolla (Azolla anabaena L) Genotypes to The Mediterranean and Aegean Coastline Ecological Conditions

Table 2. Average temperatures $\left({ }^{\circ} \mathrm{C}\right)$ and relative humidity (\%) values in Izmir in 2002, 2003and 2004.

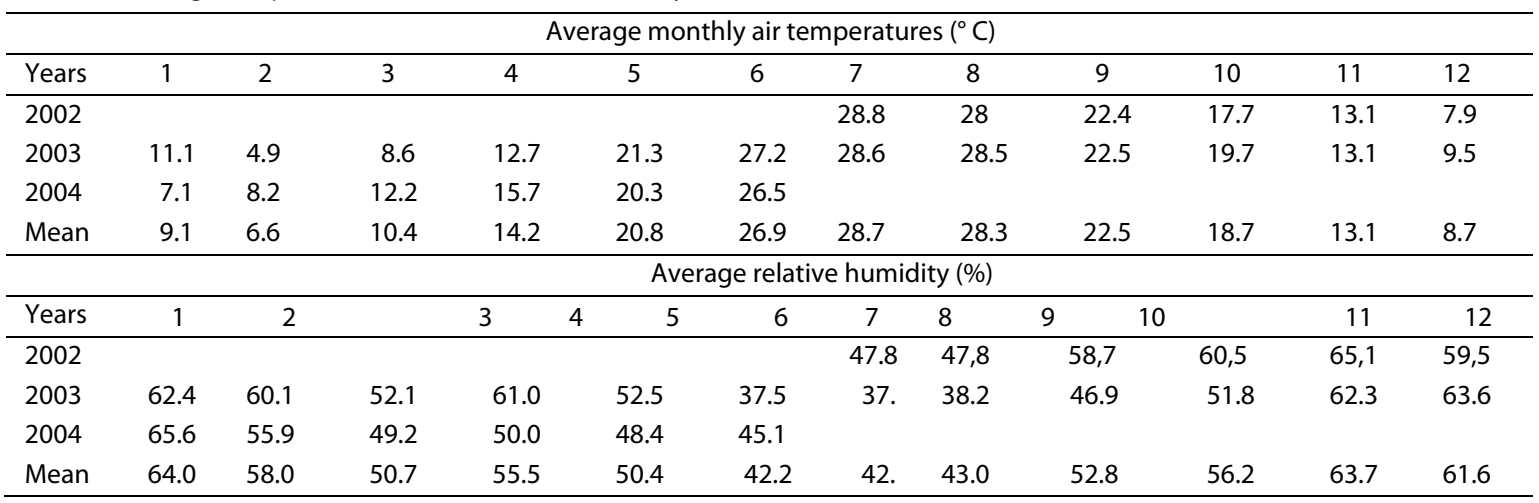

Table 3. Inoculation dates of genotypes (2002-3 and 2003-4).

\begin{tabular}{ccccccccccccc}
\hline \multicolumn{10}{c}{ Months } \\
\hline Years & 1 & 2 & 3 & 4 & 5 & 6 & 7 & 8 & 9 & 10 & 11 & 12 \\
\hline 2002 & & & & & & & 08 & 05 & 02 & 07 & 04 & 09 \\
2003 & 06 & 03 & 03 & 03 & 07 & 05 & 02 & 07 & 04 & 08 & 06 & 01 \\
2004 & 05 & 09 & 05 & 03 & 07 & & & & & & & \\
\hline
\end{tabular}

\section{RESULTS and DISCUSSION}

The amount of dry matter of azolla genotypes (FI-1040, CA-3510, MI-4030, A.F Edirne and ME-2026) were determined between the years 2002-2003 and
2003-2004 by analysis of variance. Only genotype factor was found significant and year and time effect were not found significantly (Table 4). Binary and ternary interactions were not found statistically significant.

Table 4. The F values for dry matter amounts of genotypes (2002-2004).

\begin{tabular}{lll}
\hline & DF & dry matter amount $\left(\mathrm{g} \mathrm{m}^{-2}\right)$ \\
\hline Rep. & 2 & $0,010 \mathrm{~ns}$ \\
Year & 1 & $0,523 \mathrm{~ns}$ \\
Genotype & 4 & $60,142^{* *}$ \\
Month & 11 & $1,801 \mathrm{~ns}$ \\
Year x Genotype & 4 & $0,414 \mathrm{~ns}$ \\
Year x Mont & 11 & $0,235 \mathrm{~ns}$ \\
Genotype x Month & 44 & $0,821 \mathrm{~ns}$ \\
Year x Genotype x Month & 44 & $0,170 \mathrm{~ns}$ \\
CV (\%) & & $29,41 \%$ \\
\hline
\end{tabular}

** :significant at 0.01 probability level

Ns:refers to not significant

Between genotypes, the highest dry matter yield was obtained in August from genotype Fl-1040 (85.8 g $\mathrm{m}^{-2}$ ). Total annually dry matter content was found $641.0 \mathrm{~g} \mathrm{~m} \mathrm{~m}^{-2}$ according to monthly average of genotypes. The average of two years (14 days per month) of genotypes were found as $53.4 \mathrm{~g} \mathrm{~m}^{-2}$ (Table.5).

There was no statistically important differences between the monthly average dry matter yields of MI4030 and FI-1040 and the yields were 68.2 and $67.8 \mathrm{~g}$ $\mathrm{m}^{-2}$, respectively (Table 5 ). In the other hand, while there was no significant differences between genotypes MI-4030 (818.4 $\left.\mathrm{g} \mathrm{m}^{-2}\right)$ and $\mathrm{Fl}-1040(813.6 \mathrm{~g}$ $\left.\mathrm{m}^{-2}\right)$, whereas genotypes A.F Edirne $\left(518.4 \mathrm{~g} \mathrm{~m}^{-2}\right), \mathrm{ME}$ $2026\left(636.0 \mathrm{~g} \mathrm{~m}^{-2}\right)$ and $3510\left(420.0 \mathrm{~g} \mathrm{~m}^{-2}\right)$ had lower average annual dry matter yields (Table 5 ).

It is shown in Table 5 that genotype Fl-1040 gave the highest dry matter yield $\left(85.8 \mathrm{~g} \mathrm{~m}^{-2}\right)$ in August, whereas genotype Ml-4030 had the highest yield (80.1 $\mathrm{g} \mathrm{m}^{-2}$ ) in September as monthly average dry matter yields. 
Table 5. Dry matter content belongings to genotypes during the experiments of 2002-2004 $\left(\mathrm{g} \mathrm{m}^{2}\right)$.

\begin{tabular}{|c|c|c|c|c|c|c|c|c|}
\hline \multicolumn{7}{|c|}{ Dry matter content $\left(\mathrm{g} \mathrm{m}^{2}{ }^{2}\right)$} & \multicolumn{2}{|c|}{ Average yield for 2 years } \\
\hline Months & $\mathrm{FI}-1040$ & CA-3510 & MI-4030 & A.F (Edirne) & $\begin{array}{l}\text { ME - } \\
2026\end{array}$ & Average & $\begin{array}{c}\text { Dry Matter } \\
\text { Content }\left(\mathrm{g} \mathrm{m}^{-2}\right)\end{array}$ & Genotypes \\
\hline Jul. & 78.7 & 36.8 & 69.8 & 44.1 & 50.0 & 55.9 & 78.7 & $\mathrm{FI}-1040$ \\
\hline Aug. & 85.8 & 41.7 & 64.8 & 43.3 & 48.6 & 56.8 & 85.8 & $\mathrm{FI}-1040$ \\
\hline Sep. & 69.1 & 40.6 & 80.1 & 47.5 & 63.6 & 60.2 & 80.1 & Ml-4030 \\
\hline Oct. & 75.2 & 37.5 & 59.6 & 50.3 & 52.5 & 55.0 & 75.2 & $\mathrm{FI}-1040$ \\
\hline Nov. & 67.9 & 31.3 & 59.5 & 41.8 & 51.1 & 50.3 & 67.9 & $\mathrm{FI}-1040$ \\
\hline Dec. & 52.9 & 28.7 & 70.7 & 41.1 & 44.7 & 47.6 & 70.7 & Ml-4030 \\
\hline Jan. & 56.6 & 32.4 & 59.8 & 39.6 & 45.7 & 46.8 & 59.8 & Ml-4030 \\
\hline Feb. & 62.2 & 38.3 & 64.9 & 38.6 & 56.8 & 52.2 & 64.9 & Ml-4030 \\
\hline Apr. & 67.7 & 39.5 & 70.1 & 44.6 & 59.6 & 56.3 & 70.1 & MI-4030 \\
\hline May & 69.9 & 36.1 & 66.5 & 42.3 & 53.5 & 53.6 & 68.2 & $\mathrm{FI}-1040 / \mathrm{Ml}-4030$ \\
\hline Jun. & 68.2 & 30.1 & 79.3 & 45.6 & 46.2 & 53.8 & 79.3 & Ml-4030 \\
\hline$A v_{1} .^{*}$ & $67.8 \mathrm{~A}$ & 35.0 D & $68.2 \mathrm{~A}$ & $43.2 \mathrm{C}$ & $53.0 \mathrm{~B}$ & 53.4 & 72.8 & \\
\hline Total yield ${ }_{2}^{* *}$ & $813.6 \mathrm{~A}$ & $420.0 \mathrm{D}$ & $818.4 \mathrm{~A}$ & $518.4 C$ & $636.0 \mathrm{~B}$ & 641.0 & 873.6 & \\
\hline $\begin{array}{l}\text { An. }{ }^{* * *} \text { total } \\
\text { yield }_{3}\end{array}$ & $1627.0 \mathrm{~A}$ & $840.0 \mathrm{D}$ & $1636.0 \mathrm{~A}$ & $1036.8 C$ & $1272.0 \mathrm{~B}$ & 1282.0 & 1747.2 & \\
\hline $\begin{array}{l}\text { Average } \\
\text { increase }\end{array}$ & +12.7 & -66.0 & +12.8 & -81.5 & 100 & & +13.7 & \\
\hline \multicolumn{9}{|c|}{$\begin{array}{l}\mathrm{HKO}_{1}=249.4, \mathrm{LSD}(\% 5)=5.1 \\
\mathrm{HKO}_{2}=188,2, \mathrm{LSD}(\% 5)=25.8 \\
\mathrm{HKO}_{3}=155,9, \mathrm{LSD}(\% 5)=23,5\end{array}$} \\
\hline
\end{tabular}

*Average yield of 2 years (14 days per month)

**Total average yield of year (14 days per month)

***Total average annual yield (12 months)

The genotype ME-2026 which was used as a standart genotype in the trial showed higher performance in April $\left(59.6 \mathrm{~g} \mathrm{~m}^{-2}\right)$ and September (63.6 $\mathrm{g} \mathrm{m}^{-2}$ ) (Table 5).

ME-2026 genotype gave the highest dry matter yields on April and September. On the other hand, the genotypes $\mathrm{Fl}-1040$ and $\mathrm{Ml}-4030$ gave the highest yields than ME-2026 the all year. According to these results, we can say that it is possible to have high dry matter yields from Azollae genotypes the all year in Aegean and Mediterranean conditions.

\section{CONCLUSION}

Dry matter amount of five different azolla genotypes were investigated for two years in this experiment. The genotypes Ml-4030 and FI-1040 showed better performance for the Aegean and Mediterranean coastline ecological conditions than the other genotypes and their annual dry matter production reached to 16 ton/ha an increase $13.7 \%$. It could be said that these genotypes can be used for azolla production for 12 months a year.

\section{ACKNOWLEDGEMENTS}

The author thanks Ege University SRP coordinator (Project of 2002/ZRF.007) for its funding of this research.

\section{REFERENCES}

Ashton, P.J. 1971. Effect of some environmental factors on the growth of Azolla fliculoides Lam., The Orange River, Progress Report, Inst. For Environmental Sciences University of the O.F.S., South Africa. pp:123-136.

Aysel, F., M.N. Gevrek. 2003. Determinations of some features and two azola genotip species from TURKEY. Msc.Thesis, E.U. Graduate School of Natural and Applied Sciences.

Gevrek, M.N., B.Yağmur, B.Sabanc1, O. Arabac1. 2004. Studies on the adaption of Azolla mexicana in the Aegean and the Mediterranean regions. Plant Prod. Sci. 7(1):50-54.

Hove, C. Van. 1989. Azolla and its multiple uses on Africa. F.A.O. 42.

Khan, M. 1987. Is Azolla a viable supplement and/or substitute for chemical fertilizer SERCA technical bulletin 3: 1-12. 
Stell, R.G.D., J.H. Torrie. 1980. Principles and procedures of statistics:A Biometric Approach. 2 nd ed. Mc Graw-Hill, NY. USA.

Talley, S.N., B.J. Talley, R.W. Rains. 1977. In D. A. Hollaender et al. eds., Nitrogen fixation by Azolla in rice field. Plenum Press, New York. pp:259-281.

Thomas, A., D.L.Lumpkin and Pluckne. 1982. Azolla as a Green manure: use and management in crop production. Westview Tropical Agriculture Series, No.5. Library of Congress Catalog Card Number 82-50919 ISBN 0-89158-451-X.

Venture, W., I. Watanabe, 1990. Azolla and sesbania: organic fertilizers., IRRI. Manilla. Philippines.
Venture, W., I. Watanabe, C. Ramirez, G. Mascarina, B. Padre, 1990. Azolla decomposition and availability of its nitrogen to lowland rice. Transaction of 14 th International Congress of Soil Science, Kyoto, Japan.

Watanabe, I., C.R. Espinas, N.S.Berja, B.V., Alimagno. 1977. Utilization of Azolla-Anabaena complex as a nitrogen fertilizer for rice. IRRI Research Paper Series N: 11, November.

Wilbur,V,, I. Watanabe, 1980. Azolla and sesbania: organic fertilizers, Philippine Environment Conference on 14-18 June, Manila. 